\title{
Analisis Kebutuhan dan Ketersediaan Air Domestik Menggunakan Metode Regresi di Kota Bogor
}

\author{
(Analysis of Domestic Water Supply and Demand Using Regression Method in Bogor \\ City)
}

\author{
Virssa Noperissa ${ }^{1}$, dan Roh Santoso Budi Waspodo ${ }^{1^{*}}$ \\ ${ }^{1}$ Departemen Teknik Sipil dan Lingkungan, Fakultas Teknologi Pertanian, Institut Pertanian Bogor. \\ Jl. Raya Dramaga, Kampus IPB Dramaga, PO BOX 220, Bogor, Jawa Barat Indonesia \\ *Penulis korespondensi: rohsbw@yahoo.com
}

Diterima: 01 Oktober 2018

Disetujui: 27 November 2018

\begin{abstract}
Increasing of population in a region is directly proportional to its development. Large number of populations resulted in the wider construction of residential areas. Construction of residential areas requires a clean water supply to fulfill households water demand. The purpose of this research were to analyze the domestic water demand and water availability in Bogor City, and to analyze the suitability between the domestic water supply and demand in Bogor City. The research was done from February to May 2018. This research needed data of population, hydrogeological map and annual river discharge. The correlation between population to domestic water demand using regression method was showed with equation $Y=19549 X+801520$. In 20 years ahead domestic water demand will 80,328,688.57 $\mathrm{m}^{3}$ and total water demand will 125,312,754.2 $\mathrm{m}^{3}$, while total surface water availability will 174,078,720 $\mathrm{m}^{3} /$ year. Domestic water availability in Bogor would decrease and would make clean water shortage after 2049 when population reached 1,720,323 persons.
\end{abstract}

Key words: domestic, surface water, water demand, water supply.

\section{PENDAHULUAN}

Laju pertumbuhan penduduk di suatu wilayah berbanding lurus dengan pembangunan di wilayah tersebut, hal ini dapat dilihat dari semakin banyaknya jumlah penduduk maka semakin meluas pembangunan areal pemukiman suatu wilayah. Perkembangan wilayah tersebut menyebabkan kebutuhan air bersih terus meningkat. Sementara itu ketersediaan air bersih terbatas bahkan akibat perlakuan manusia yang kurang baik dalam menjaga kelangsungan sumber-sumber air menyebabkan tingkat ketersediaan sumber daya air menurun, sehingga diperlukan prediksi dan perencanaan dengan pemanfaatan sebaik mungkin (Mokoginta dan Mangangka 2015).
Pembangunan areal pemukiman juga tentunya memerlukan ketersediaan air bersih untuk memenuhi kebutuhan air domestik (rumah tangga). Kebutuhan air domestik meliputi kebutuhan untuk minum, memasak, sanitasi, membersihkan rumah, mencuci pakaian, mencuci kendaraan, menyiram kebun, air mancur dan kolam renang. Sementara kebutuhan di luar rumah meliputi kebutuhan untuk menyiram kebun, air mancur dan kolam renang. Kebutuhan untuk kran umum adalah kebutuhan untuk kran yang dimanfaatkan oleh publik. (Twort dan Ratnayaka 2003). Sedangkan ketersediaan air dalam pengertian sumberdaya air pada dasarnya berasal dari sumur dangkal, sumur dalam, mata air, air permukaan dan penampungan air hujan (danau, waduk dan situ) yang mengalami siklus hidrologi 
dan sebagian lagi akan meresap jatuh ke tanah sebagai pengisian kembali (recharge) pada kandungan air tanah yang ada (Sari et al. 2006).

Ketersediaan air berdasarkan sumber air tersebut merupakan salah satu modal dasar pembangunan, sehingga perlu tindakan bijak agar ketersediaan menurut kualitas dan kuantitas nya terjaga dan tidak merusak keseimbangan ekosistem lingkungan. Selain itu penyediaan air yang baik harus mampu melayani kebutuhan air yang memadai serta mendapat respon serta dukungan yang positif dari masyarakat (Yuliani dan Rahdriawan 2014).

Jawa Barat merupakan provinsi dengan penduduk terbanyak dan terpadat di Indonesia. Jumlah penduduk Jawa Barat pada tahun 2015 mencapai 46.709.600 jiwa sedangkan pada tahun 2010 mencapai 43,05 juta (BPS 2016). Maka laju pertumbuhan penduduk 20102015 sebesar 1,56 \%, Bappenas (2013) dalam proyeksi penduduk Indonesia 20102035 memprediksi jumlah penduduk provinsi Jawa Barat pada tahun 2035 akan mencapai 57.137.300 jiwa, untuk itu perlu adanya data jumlah penduduk dan kebutuhan air dalam rangka mencapai pembangunan yang berkelanjutan. Dalam penelitian ini akan diidentifikasi penggunaan air berlokasi di salahsatu kota yang ada di Jawa Barat yaitu kota Bogor, sehingga dapat diketahui nilai debit kebutuhan air domestik dan ketersediaan airnya, serta mengetahui nilai korelasi peningkatan jumlah penduduk terhadap kebutuhan air dan ketersediaan air di Kota Bogor.

\section{METODOLOGI}

Penelitian mengenai analisis kebutuhan dan ketersediaan air domestik yang ada di Kota Bogor dilaksanakan dari bulan Maret hingga Mei 2018.
Penelitian ini menggunakan data sekunder. Data sekunder yang dibutuhkan dalam penelitian ini diantaranya adalah data debit Sungai Ciliwung dan Sungai Cisadane, cekungan airtanah Kota Bogor, iklim Kota Bogor dan kependudukan Kota Bogor. Alat yang digunakan yaitu seperangkat komputer yang dilengkapi dengan perangkat lunak Microsoft Word, Microsoft Excel, dan alat tulis.

Penelitian diawali dengan melakukan pendefinisian masalah dan studi literatur untuk menentukan tujuan akhir dari penelitian yang dilakukan serta memperoleh dasar teori yang dibutuhkan. Kegiatan penelitian ini mencakup studi pustaka, pengumpulan data, pengolahan data, analisis data, serta pengambilan kesimpulan. Bagan alir penelitian dapat dilihat pada Gambar 1.

Metode studi pustaka dilakukan untuk mendapatkan pengetahuan dalam melakukan atau menganalisis permasalahan yang diteliti. Studi pustaka ini dapat diperoleh dalam bentuk publikasi ilmiah atau jurnal tentang aspek yang digunakan dalam menganalisis permasalahan.

Data yang digunakan pada penelitian ini adalah data sekunder. Data sekunder ini didapatkan dari Badan Pusat Statistik Provinsi Jawa Barat, Balai Pengelolaan DAS Citarum-Ciliwung dan Badan Geologi.

Analisis kebutuhan air domestik ditentukan dengan menghitung jumlah penduduk 20 tahun mendatang. Perhitungan total kebutuhan air didasarkan pada kebutuhan air domestik, kebutuhan air non domestik dan kehilangan air. Menurut Direktorat Jendral Cipta Karya (DepPU 2000) besar kebutuhan air domestik dan non domestik dihitung dengan menggunakan Persamaan (1), (2).

$\mathrm{Qd}=\mathrm{Yn} \cdot \mathrm{Rk}$

$\mathrm{Qn}=\mathrm{Qd} \cdot \mathrm{m}$ 
Perhitungan kehilangan air dapat diketahui dengan menggunakan Persamaan (3) (Gaib et al 2016). Perhitungan total kebutuhan air dapat ditentukan dengan Persamaan (4).

$\mathrm{Qs}=(\mathrm{Qd}+\mathrm{Qn}) \times 20 \%$

$\mathrm{Qt}=\mathrm{Qd}+\mathrm{Qn}+\mathrm{Qs}$

Keterangan :

Qd : Kebutuhan air domestik (lt/hari)

Yn : Proyeksi pertumbuhan tahun ke $-\mathrm{n}$ (jiwa)

Rk : Angka konsumsi air bersih berdasarkan kategori kota (lt/org/hari)

Qn : Kebutuhan air non domestik (lt/hari)

$\mathrm{m}$ : Angka presentase non domestik (\%)

Qs : Kehilangan air (lt/hari)

Qt : Total kebutuhan air (lt/hari)

Analisis ketersediaan air menggunakan data debit andalan sungai dan airtanah. Prosedur perhitungan ketersediaan debit andalan dilakukan dengan metode tahun dasar perencanaan (basic year).

$\mathrm{P}=\mathrm{m} /(\mathrm{n}+1) \times 100 \%$

Keterangan :

P : probabilitas (\%)

m : nomor urut data

n : jumlah data

Ketersediaan air di suatu stasiun diperlukan debit aliran yang bersifat runtut (time series), misalnya data debit harian sepanjang tahun selama beberapa tahun (Zulkipli et al. 2013). Analisis potensi airtanah diperoleh melalui data cekungan airtanah Kota Bogor. Airtanah terdapat pada formasi geologi yang dapat menyimpan dan melalukan air dalam jumlah yang besar, yang dikenal sebagai akuifer (Purnama et al. 2007). Analisis kesetimbangan antara ketersediaan dan kebutuhan air berdasarkan neraca air
Thornthwaite dan Mather (Wijayanti et al 2015).

$\mathrm{P}=\mathrm{Et}+\mathrm{ds}+\mathrm{Ro}$

Keterangan :

P : presipitasi/curah hujan ( $\mathrm{mm})$,

Et : evapotranspirasi ( $\mathrm{mm})$,

ds : perubahan cadangan air dalam $\operatorname{tanah}(\mathrm{mm})$,

Ro : limpasan (mm)

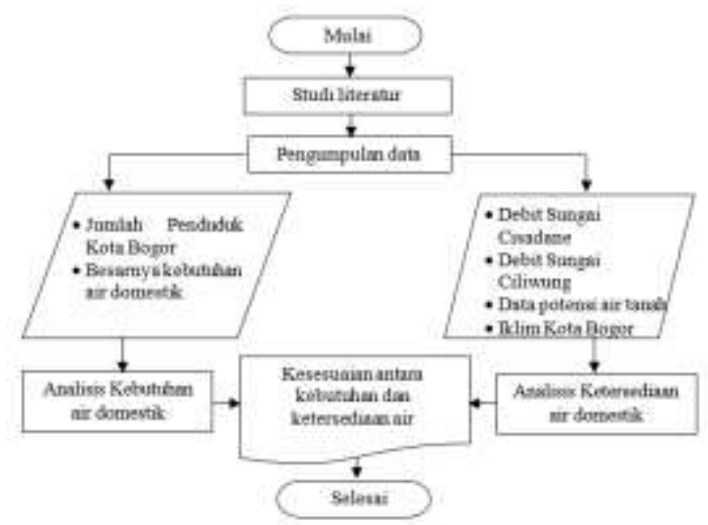

Gambar 1 Bagan alir penelitian

\section{HASIL DAN PEMBAHASAN}

\section{Keadaan Umum Kota Bogor}

Secara geografis Kota Bogor terletak di antara $106^{\circ} 48^{\prime}$ BT dan $6^{0} 26^{\prime}$ LS, kedudukan geografis Kota Bogor di tengah-tengah wilayah Kabupaten Bogor serta lokasinya sangat dekat dengan Ibukota Negara, merupakan potensi yang strategis bagi perkembangan dan pertumbuhan ekonomi dan jasa, pusat kegiatan nasional untuk industri, perdagangan, transportasi, komunikasi, dan pariwisata Kota Bogor mempunyai rata-rata ketinggian minimum $190 \mathrm{~m}$ dan maksimum $330 \mathrm{~m}$ dari permukaan laut. Kondisi iklim selama tahun 2016 di Kota Bogor suhu rata-rata tiap bulan $31,8^{0} \mathrm{C}$ (maksimal) dan suhu rata-rata terendah $23,3^{0}$ C. Suhu tertinggi terjadi pada bulan April 2016 yang tercatat $32,7^{0} \mathrm{C}$ dan terendah tercatat $22,7^{0}$ C. Kelembaban udara 93,6\%, curah hujan rata-rata setiap 
bulan sekitar 365,6 - 402,9 mm dengan curah hujan terbesar pada bulan September 2016. Luas wilayah Kota Bogor sebesar 11.850 ha terdiri dari 6 kecamatan dan 68 kelurahan. Kemudian Secara Administratif Kota Bogor dikelilingi oleh wilayah Kabupaten Bogor dengan batas wilayah sebagai berikut :

a. Sebelah Utara berbatasan dengan Kec. Kemang, Bojong Gede, dan Kec. Sukaraja Kabupaten Bogor.

b. Sebelah Timur berbatasan dengan Kec. Sukaraja dan Kec. Ciawi, Kabupaten Bogor.

c. Sebelah Barat berbatasan dengan Kec. Darmaga dan Kec. Ciomas, Kabupaten Bogor.

d. Sebelah Selatan berbatasan dengan Kec. Cijeruk dan Kec. Caringin, Kabupaten Bogor.

Tabel 1 Luas wilayah menurut kecamatan

\begin{tabular}{clc}
\hline No & Kecamatan & Luas Wilayah (ha) \\
\hline 1 & Bogor Selatan & 30.81 \\
2 & Bogor Timur & 10.15 \\
3 & Bogor Utara & 17.72 \\
4 & Bogor Tengah & 8.13 \\
5 & Bogor Barat & 32.85 \\
6 & Tanah Sareal & 18.84 \\
& Jumlah & 118.50 \\
\hline
\end{tabular}

\section{Proyeksi Penduduk Kota Bogor}

Penduduk Kota Bogor pada tahun 2016 terdapat sebanyak 1.064 .687 orang yang terdiri atas 540.288 orang laki-laki dan sebanyak 524.399 orang perempuan. Dibandingkan dengan tahun 2015 jumlah penduduk Kota Bogor pada tahun 2016 bertambah sebanyak 16.765 orang atau meningkat sebanyak $1,60 \%$. Dengan luas wilayah $118.50 \mathrm{Km}^{2}$, kepadatan penduduk di Kota Bogor pada tahun 2016 mencapai 8.985 orang per $\mathrm{Km}^{2}$. Berdasarkan catatan Badan Pusat Statistik Kota Bogor dari tahun 2003 sampai dengan tahun 2016 jumlah penduduk yang ada disajikan dalam Tabel 2.
Jumlah penduduk di Kota Bogor dari tahun ke tahun cenderung meningkat. Berdasarkan data tersebut hubungan jumlah penduduk terhadap tahun dapat disebut sebagai data berkala (times series), sehingga metode yang digunakan untuk memproyeksikan jumlah penduduk pada masa yang akan datang adalah 4 metode regresi sebagai perbandingan. Keempat metode tersebut antara lain regresi eksponensial, regresi linier, regresi logaritma dan regresi polynominal (Syafruddin et al. 2007).

Menurut Peraturan Menteri Negara Lingkungan Hidup Nomor 01 (MenLH 2007) tentang Pedoman Pengkajian Teknis untuk Menetapkan Kelas Air, perencanaan minimal kebutuhan air yang akan datang adalah 10 tahun. Oleh sebab itu, perhitungan kebutuhan air domestik dalam penelitian ini diproyeksikan selama 20 tahun yaitu dari tahun 2017 sampai dengan 2036. Pada Gambar 2 ditunjukkan perbandingan keempat metode regresi yang digunakan sebagai proyeksi jumlah penduduk dengan 14 data aktual (20032016) dan 20 data ramalan (2017-2036) yang ada di Kota Bogor.

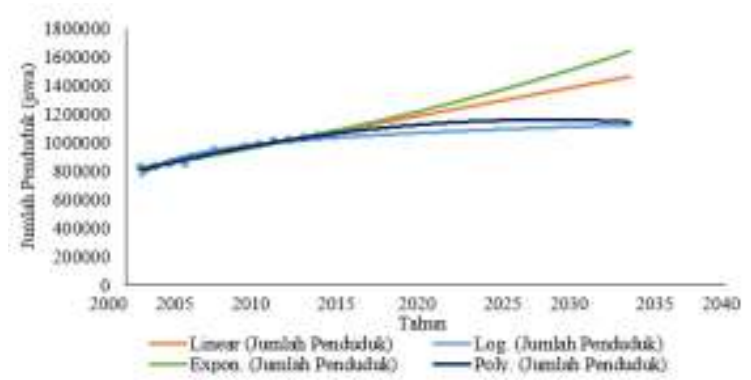

Gambar 2 Proyeksi jumlah penduduk 2003 sampai 2036

Dari Gambar 2 diperoleh persamaan, korelasi dan juga standar deviasi dari keempat hasil regresi untuk menentukan analisis kebutuhan air domestik. Persamaan yang diperoleh disajikan pada Tabel 3. 
Tabel 2 Jumlah penduduk Kota Bogor

\begin{tabular}{cccc}
\hline Tahun & Jumlah Penduduk & Tahun & Jumlah Penduduk \\
\hline 2003 & 820.707 & 2010 & 969.486 \\
2004 & 831.571 & 2011 & 987.315 \\
2005 & 855.085 & 2012 & 1.004 .831 \\
2006 & 855.085 & 2013 & 1.013 .019 \\
2007 & 905.132 & 2014 & 1.030 .720 \\
2008 & 942.204 & 2015 & 1.047 .922 \\
2009 & 946.204 & 2016 & 1.064 .687 \\
\hline
\end{tabular}

Tabel 3 Persamaan regresi dengan keempat metode

\begin{tabular}{llcc}
\hline \multicolumn{1}{c}{ Hasil Regresi } & \multicolumn{1}{c}{ Persamaan } & Korelasi $\left(\mathrm{R}^{2}\right)$ & Standar Deviasi \\
\hline Exponensial & $\mathrm{y}=808037 \mathrm{e}^{0,0208 \mathrm{x}}$ & 0,9713 & 79411,86 \\
Logaritma & $\mathrm{y}=101362 \ln \mathrm{x}+765753$ & 0,9012 & 79645,30 \\
Linier & $\mathrm{y}=19549 \mathrm{x}+801520$ & 0,979 & 78804,54 \\
Polynominal & $\mathrm{y}=-467,03 \mathrm{x}^{2}+26555 \mathrm{x}+782839$ & 0,9862 & 79094,08 \\
\hline \multicolumn{2}{c}{ Berdasarkan Tabel 3 keempat hasil air domestik di masa yang akan datang }
\end{tabular}

regresi mempunyai nilai koefisien korelasi (R) sangat kuat. Menurut Sudjana (1982) disebutkan bahwa nilai koefisien $\mathrm{R}$ termasuk dalam kategori sangat kuat jika bernilai antara $0,80-1,00$ sehingga dengan keempat hasil regresi tersebut, korelasi jumlah penduduk terhadap kebutuhan air domestik termasuk dalam kategori sangat kuat. Pertimbangan kedua yaitu nilai standar deviasi sebagai penilaian tentang seberapa jauh letak nilai sentral terhadap datanya, serta mempelajari bagaimana kualitas suatu sampel (Taufik 2005). Dengan demikian metode regresi linier adalah metode terbaik yang dipilih berdasarkan nilai korelasi yang mendekati 1 dan standar deviasi terkecil, maka akan diperoleh proyeksi kebutuhan air domestik setiap tahunnya.

\section{Kebutuhan Air Domestik}

Tinjauan jumlah penduduk merupakan faktor utama yang dapat mempengaruhi besaran kebutuhan air domestik pada suatu wilayah saat ini, sedangkan untuk mengetahui kebutuhan dapat dihitung dengan menggunakan metode regresi linier. Hasil dan analisa perkembangan jumlah pengguna air dapat digunakan sebagai dasar dalam perhitungan perencanaan sistem penyediaan air untuk memenuhi kebutuhan air saat ini dan masa yang akan datang (Hasibuan 2013).

Kebutuhan air domestik dihitung berdasarkan standar baku mutu yang ditetapkan Ditjen Cipta Karya (DepPU 2007), sehingga jumlah penduduk mempengaruhi standar baku mutu yang digunakan. Kota Bogor pada tahun 2003 sampai 2011 tergolong sebagai kategori kota besar, sehingga standar kebutuhan air yang digunakan adalah sebesar 130 liter/orang/hari, sedangkan tahun 2012 sampai 2036 (hasil proyeksi jumlah penduduk) tergolong sebagai kategori kota metropolitan dengan standar kebutuhan air 150 liter/orang/hari. Menggunakan tingkat pertumbuhan penduduk di Kota Bogor dan mengalikannya dengan standar kebutuhan air maka akan didapatkan kebutuhan air domestik setiap tahunnya. 
Metode regresi linier dengan persamaan kebutuhan air domestik berdasarkan jumlah penduduk adalah $\mathrm{y}=$ $19549 x+801520$ dengan nilai $\mathrm{R}^{2}$ sebesar 0,979 yang diperoleh berdasarkan output statistika regresi linier pada Tabel 4. Dengan demikian dapat diperkirakan kebutuhan air domestik di Kota Bogor 20 tahun mendatang. Pada tahun 2036 kebutuhan air domestik sebesar 219.927,9 $\mathrm{m}^{3} /$ hari atau setara dengan $80.328 .688,57$ $\mathrm{m}^{3} /$ tahun.

Sementara untuk mencapai kesetimbangan ketersediaan air baku yang ada, dibutuhkan beberapa nilai kebutuhan air lainnya seperti kebutuhan non domestik dan kehilangan airnya yang diperoleh berdasarkan perhitungan yang menggunakan Persamaan 1,2 dan 3. Hasil perbandingan kebutuhan air domestik dan kebutuhan air lainnya disajikan pada Gambar 3.

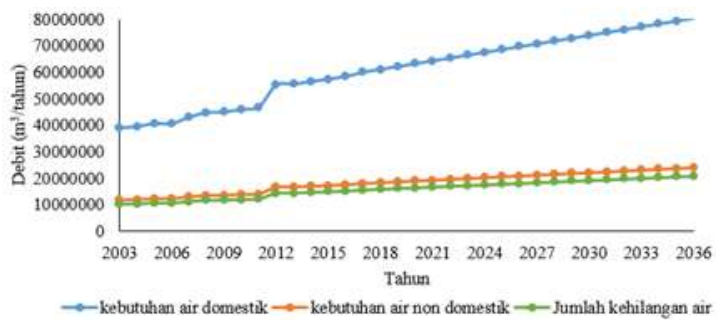

Gambar 3 Kebutuhan air baku Kota Bogor

Berdasarkan Gambar 3 kebutuhan air domestik lebih tinggi daripada kebutuhan air non domestik, hal ini disebabkan kebutuhan air non domestik diperoleh berdasarkan persentase terhadap besarnya kebutuhan air domestik. Direktorat Jenderal Cipta Karya ( DepPU 2000) memperkirakan besarnya kebutuhan air non domestik sebesar 20\% - 30\% dari kebutuhan air domestik. Adapun jumlah kehilangan air sebesar $20 \%$ dari penjumlahan kebutuhan air domestik dan non domestik, sehingga dari ketiga nilai tersebut dapat diperoleh total kebutuhan air baku di Kota Bogor 20 tahun mendatang sebanyak $343.087,52 \mathrm{~m}^{3} /$ hari atau setara dengan 125.312.754,2 $\mathrm{m}^{3} /$ tahun.

\section{Ketersediaan Air}

Pemanfaatan sumber daya air sebagai sumber untuk memenuhi kebutuhan air Kota Bogor adalah air permukaan dan potensi airtanah. Kota Bogor dilewati oleh 2 sungai yaitu Sungai Ciliwung dan Sungai Cisadane. Potensi airtanah dapat diketahui berdasarkan cekungan airtanah di Kota Bogor.

\section{Air Permukaan}

Ketersediaan air sungai untuk pemanfaatan air ditentukan berdasarkan ketersediaan debit sungai andalan. Dalam menentukan besarnya ketersediaan air atau debit andalan sungai dilakukan dengan metode tahun dasar perencanaan (basic year). Analisis ketersediaan air pada air permukaan mengacu pada SNI No.6738 (BSN 2015) yaitu melakukan perhitungan debit andalan sungai dengan kurva durasi debit. Penggambaran ketersediaan air di Indonesia pada lokasi sungai biasanya menggunakan probabilitas $80 \%, 90 \%$ dan $95 \%$.

Data yang menjadi parameter dalam menentukan debit andalan adalah data debit yang memiliki pencatatan data minimal 10 tahun dengan interval bulanan. Berdasarkan studi yang dilakukan oleh Badan Pengelolaan Sumber Daya Air Kota Bogor menunjukan data debit Sungai Ciliwung Pos Katulampa dan Cisadane Pos Empang 2007-2016. Berdasarkan data tersebut dapat dihitung nilai probabilitas dari data debit yang telah disusun dari besar ke kecil dengan menggunakan Persamaan (5). Berdasarkan hasil perhitungan tersebut diperoleh probabilitas debit kedua sungai seperti pada Gambar 4. 


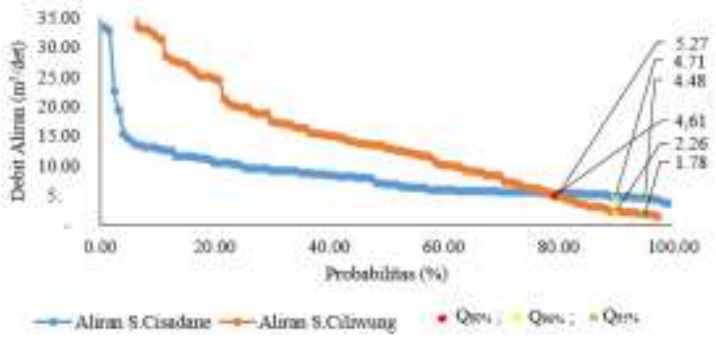

Gambar 4 Probabilitas debit S.Ciliwung dan S.Cisadane 2007-2016

Berdasarkan Gambar 4 diperoleh debit andalan Sungai Cisadane lebih besar dibandingkan debit Sungai Ciliwung. Hal ini disebabkan meningkatnya konversi lahan di DAS Hulu Ciliwung, sehingga pengembangan sumber daya air yang mungkin untuk memenuhi kebutuhan air baku domestik (PDAM Kota Bogor) hanya dari Sungai Cisadane. Pengembangan sumber air baku dari Sungai Ciliwung kemungkinannya sangat kecil. Fenomena penurunan debit air sungai Ciliwung diantisipasi oleh PDAM Kota Bogor dengan menghentikan pengambilan air untuk instalasi air minum, yang semula air bakunya dari Sungai Ciliwung dipindahkan ke Sungai Cisadane (Arwin dan Mukmin 2006).

Menurut SNI No.6738 tahun 2015 ketersediaan air sungai sebagai kebutuhan air baku ditentukan berdasarkan debit dengan keandalan 90\% (BSN 2015), Menurut pengamatan besarnya keandalan yang diambil untuk penyelesaian optimum penggunaan air seperti air minum adalah dengan debit keandalan 99\% (Soemarto 1986).

Tabel 4 Besarnya keandalan debit untuk berbagai keperluan

\begin{tabular}{lc}
\hline \multicolumn{1}{c}{ Kebutuhan Debit Andalan } & $\%$ \\
\hline Air Minum & 99 \\
Air Irigasi & $95-98$ \\
$\begin{array}{l}\text { Air Irigasi -Daerah beriklim } \\
\text { setengah lembab }\end{array}$ & $70-85$ \\
$\begin{array}{l}\text { Air Irigasi -Daerah beriklim } \\
\text { kering Pembangkit Listrik }\end{array}$ & \\
Tenaga Air & $85-90$ \\
\hline
\end{tabular}

Debit perencanaan yang diharapkan selalu tersedia di sungai untuk kebutuhan sektor domestik menggunakan debit andalan 99\% dengan menghitung interpolasi nilai probabilitasnya sehingga didapat debit sebesar $3,62 \mathrm{~m}^{3} /$ det yang setara dengan 114.238.512 $\mathrm{m}^{3} /$ tahun. Ketersediaan air baku dari air pemukaan dengan debit andalan 90\% sebesar 4,71 $\mathrm{m}^{3} /$ detik atau setara dengan 148.636.296 $\mathrm{m}^{3} /$ tahun.

\section{Potensi Airtanah}

Menurut Todd (1980) berdasarkan ada atau tidaknya muka airtanah maka akuifer dibedakan menjadi 2 yaitu akuifer bebas dan akuifer tertekan. Untuk memenuhi kebutuhan air domestik maupun nondomestik, biasanya digunakan akuifer tertekan. jika sumber mata air yang digunakan sebagai ketersediaan air berasal dari air tanah tertekan maka debit mata airnya tidak terpengaruh oleh musim dan dapat diasumsikan konstan sepanjang tahun. Potensi airtanah yang ada dipengaruhi oleh cekungan airtanah (CAT) pada suatu lokasi.

Berdasarkan studi yang telah dilakukan oleh Badan Geologi, hasil analisis data sumur bor di cekungan air tanah (CAT) Bogor berdasarkan ciri fisik litologi dan hidrolika yang berbeda, menunjukan sistem akuifer tertekan umumnya berada pada kedalaman antara 30-180 m bmt. Jumlah ketersediaan air tanah pada sistem akuifer tertekan mencapai 37 juta $\mathrm{m}^{3} /$ tahun (Badan Geologi 2008).

Peta konservasi air tanah CAT Bogor yang dilakukan Badan Geologi yang tercantum pada Lampiran 5. Berdasarkan konservasi air tanah yang dilakukan di CAT Bogor, untuk wilayah Kota Bogor berada pada zona rusak (zona I) dan zona kritis (zona II) sehingga pemakaian air tanah pada akuifer tertekan untuk berbagai keperluan tidak diijinkan dan dilakukan pembatasan pemakaian air 
tanah akuifer bebas (Badan Geologi 2009). Oleh karena itu upaya yang dilakukan untuk memulihkan kondisi air tanah yang rusak pasokan air bersih berasal dari air permukaan.

\section{Neraca Air}

Neraca air secara umum adalah hubungan antara aliran masuk dengan aliran keluar di suatu wilayah untuk suatu periode tertentu (Sosrodarsono dan Takeda 1993). Metode neraca air yang digunakan ialah neraca air Thornthwaite dan Mather berdasarkan Persamaan (6). Perhitungan menggunakan metode Thornthwaite mempertimbangkan curah hujan, suhu udara, indeks panas bulanan, water holding capacity (WHC) dan faktor koreksi lama penyinaran matahari berdasarkan kondisi lintang (Widiyono 2016). Data yang menunjang perhitungan neraca air lahan di Kota Bogor tersedia pada Lampiran 6.

Tabel 5 memperlihatkan bahwa di wilayah penelitian berdasarkan pengamatan curah hujan secara normal mengalami surplus/kelebihan air yakni pada bulan November sampai dengan bulan Juni. Defisit/kekurangan air terjadi pada bulan Juli sampai Oktober.

Maka diketahui bahwa neraca air suatu daerah sangat dipengaruhi oleh curah hujan, evapotranspirasi dan perubahan cadangan air dalam tanah. Sebagai ilustrasi keadaan surplus maupun defisit air dapat dilihat pada Gambar 5.

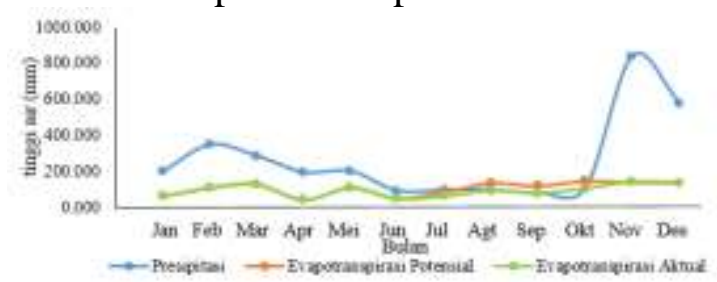

Gambar 5 Neraca air sepanjang tahun

Berdasarkan Gambar 5 Ketersediaan air dari curah hujan di wilayah Kota Bogor termasuk cukup tinggi dengan 7-8 bulan surplus. Kondisi surplus maupun defisit ini akan mempengaruhi ketersediaan air yang ada di daerah tersebut, karena kondisi surplus adalah keadaan di mana curahan hujan yang jatuh melebihi nilai kehilangan air yang terjadi di daerah tersebut yakni melalui evapotranspirasi dan infiltrasi, sedangkan kondisi defisit adalah sebaliknya. Khusus untuk kebutuhan air tanaman dalam kondisi tidak ada surplus, tetapi bukan defisit, maka yang digunakan oleh tanaman adalah lengas tanah (soil moisture).

Ketersediaan air dihitung dengan terlebih dahulu mengetahui seluruh nilai untuk parameter yang menentukannya, yaitu luas wilayah penelitian untuk masing-masing penggunaan lahan, persentase aliran, surplus air dan aliran mantapnya (Wijayanti et al 2015). Luas wilayah penelitian adalah luas potensi rawan bencana kekeringan di Kota Bogor secara keseluruhan, yakni seluas 5111,3 ha, atau seluas $43 \%$ dari luas Kota Bogor. Untuk formasi lahan, digunakan asumsi persentase aliran sebesar $25 \%$ (Langi 2007). Data ketersediaan dan kebutuhan air dapat dilihat pada Tabel 6 .

Jika nilai ketersediaan air berdasarkan limpasan air hujan 0,8 $\mathrm{m}^{3} /$ detik dijumlahkan dengan ketersediaan air permukaan berdasarkan debit andalan $90 \%$ dengan debit $4,71 \mathrm{~m}^{3} /$ detik maka akan diperoleh ketersediaan air total sebanyak $5,52 \mathrm{~m}^{3} /$ detik setara dengan $174.078 .720 \mathrm{~m}^{3} /$ tahun untuk memenuhi kebutuhan air baku di Kota Bogor. 
Tabel 5 Neraca air lahan

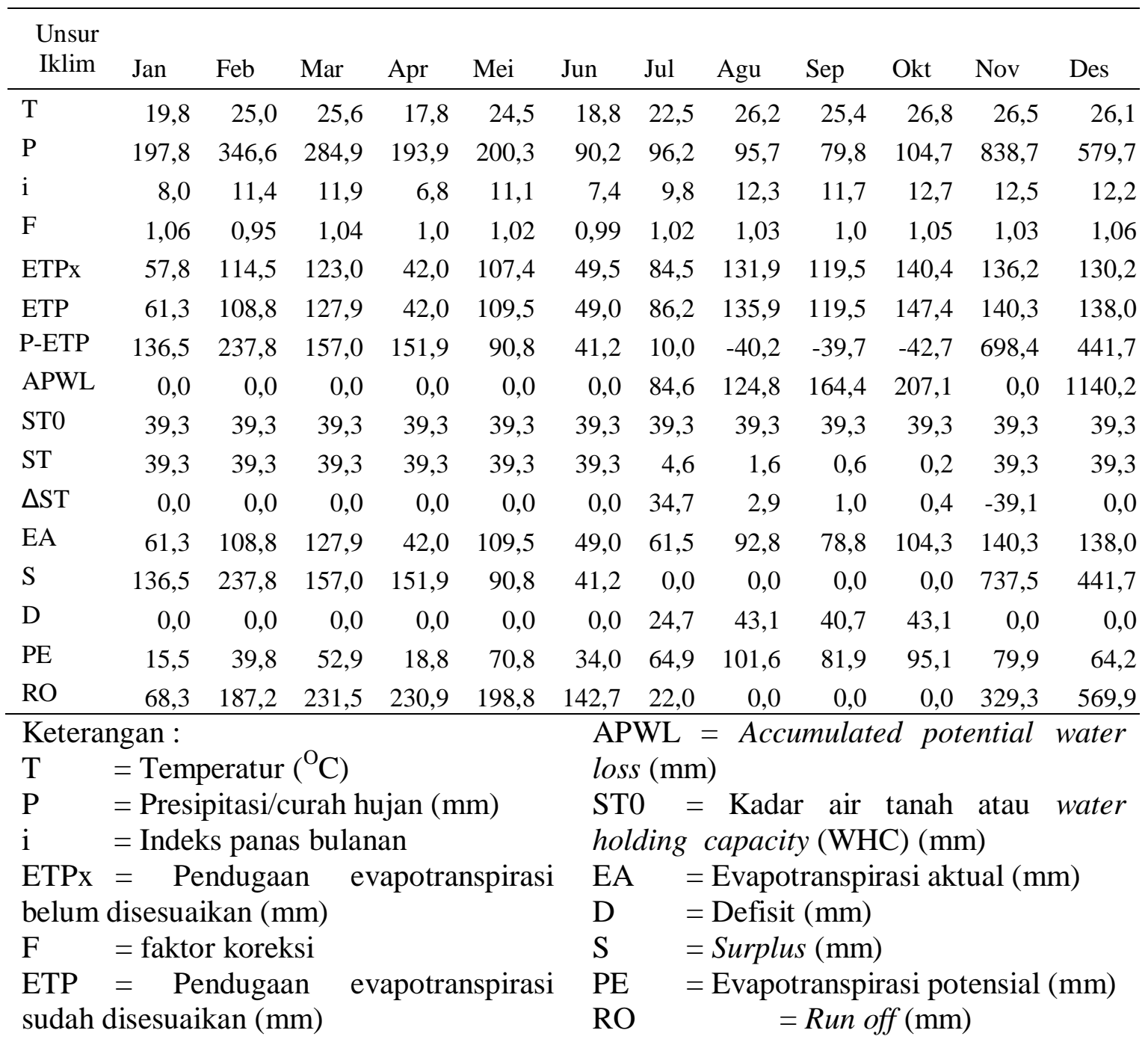

Tabel 6 Ketersediaan air berdasarkan neraca air lahan

\begin{tabular}{lrrrrr}
\hline Bulan & $\begin{array}{c}\text { Surplus } \\
(\mathrm{mm} / \mathrm{bulan})\end{array}$ & $\begin{array}{c}\text { Aliran Mantap } \\
25 \% \\
\left(\mathrm{~m}^{3} / \mathrm{detik}\right)\end{array}$ & Bulan & $\begin{array}{c}\text { Surplus } \\
(\mathrm{mm} / \mathrm{bulan})\end{array}$ & $\begin{array}{c}\text { Aliran Mantap } \\
25 \% \\
\left(\mathrm{~m}^{3} / \text { detik }\right)\end{array}$ \\
\hline Januari & 136,547 & 0,055 & Juli & 0 & 0 \\
Februari & 237,798 & 0,096 & Agustus & 0 & 0 \\
Maret & 156,96 & 0,064 & September & 0 & 0 \\
April & 151,861 & 0,061 & Oktober & 0 & 0 \\
Mei & 90,751 & 0,037 & November & 737,543 & 0,299 \\
Juni & 41,224 & 0,017 & Desember & 441,715 & 0,179 \\
& & & jumlah & 1994,399 & 0,808 \\
\hline
\end{tabular}




\section{Ketersediaan dan Kebutuhan Air}

Bertambahnya jumlah penduduk yang ada di Kota Bogor menyebabkan peningkatan jumlah kebutuhan air baku khususnya kebutuhan air domestik. Setelah diproyeksikan 20 tahun mendatang ketersediaan air masih mencukupi kebutuhan air total dengan surplus air $1,55 \mathrm{~m}^{3} /$ detik atau setara dengan 48.765.965,8 $\mathrm{m}^{3} /$ tahun. Jika diproyeksikan kembali 10 tahun mendatang, titik keseimbangan antara kebutuhan dan ketersediaan air dicapai ketika jumlah penduduk 1.720.323 jiwa pada tahun 2049. Kebutuhan dan ketersediaan air di Kota Bogor berdasarkan proyeksi jumlah penduduk pada tahun 2049 disajikan pada Gambar 6.

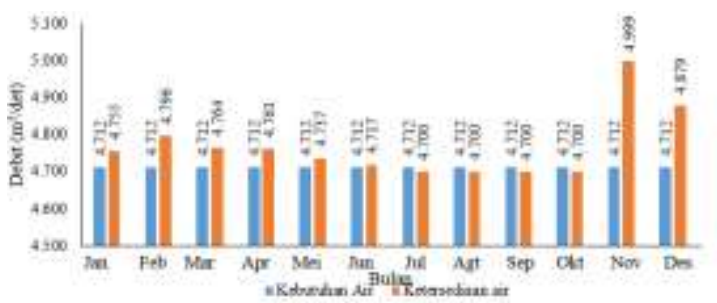

Gambar 6 Kebutuhan dan ketersediaan air di Kota Bogor

Gambar 6 menunjukkan bahwa ketersediaan air yang ada di Kota Bogor tahun 2049 mengalami defisit pada bulan kering Juli hingga Oktober sehingga pada bulan tersebut Kota Bogor mengalami kekurangan air. Hal ini sudah harus mulai menjadi fokus perhatian untuk segera ditindaklanjuti dengan adanya penelitian terbaru di wilayah Kota Bogor akibat perubahan iklim.

\section{KESIMPULAN}

Hasil analisis kebutuhan air domestik Kota Bogor untuk 20 tahun mendatang menggunakan perkiraan standar kebutuhan air bersih sebesar 80.328.688,57 $\mathrm{m}^{3}$ dan nilai kebutuhan air total 125.312.754,2 $\mathrm{m}^{3}$, sedangkan dari analisis ketersediaan air di Kota Bogor menggunakan debit probabilitas $90 \%$ dan neraca air sebagai ketersediaan air baku adalah $5,52 \mathrm{~m}^{3} /$ detik yang setara dengan $174.078 .720 \mathrm{~m}^{3} /$ tahun.

Hasil analisis kesesuaian antara kebutuhan air domestik dan ketersediaan air yang ada di Kota Bogor proyeksi 20 tahun mendatang, ketersediaan air masih mencukupi kebutuhan air total dengan surplus air 48.765.965,8 $\mathrm{m}^{3}$. Titik keseimbangan antara kebutuhan dan ketersediaan air dicapai ketika jumlah penduduk 1.720.323 jiwa pada tahun 2049.

\section{DAFTAR PUSTAKA}

Arwin A, Mukmin Y. 2006. Kajian Keandalan Air Sungai Cisadane Memenuhi Laju Permintaan Air Baku PDAM Kota Bogor. Jurnal Perencanaan Wilayah dan Kota. 17(2): 58-74.

Badan Geologi. 2008. Cekungan Air Tanah Provinsi Jawa Barat dan Daerah Khusus Ibu Kota Jakarta. Bandung (ID) : Departemen Energi Dan Sumber Daya Mineral, Pusat Lingkungan Geologi.

Badan Geologi. 2009. Penyelidikan Konservasi Cekungan Air Tanah Bogor Provinsi Jawa Barat. Bandung (ID) : Departemen Energi Dan Sumber Daya Mineral, Pusat Lingkungan Geologi.

[Bappenas] Badan Perencanaan Pembangunan Nasional. 2013. Proyeksi penduduk Indonesia 20102013. Jakarta (ID): Badan Perencanaan Pembangunan Nasional.

[BPS] Badan Pusat Statistik. 2016. Provinsi Jawa Barat dalam angka 2016. Bandung (ID): Badan Pusat Statistik Provinsi Jawa Barat. 
[BSN] Badan Standardisasi Nasional. 2015. Perhitungan Debit Andalan Sungai dengan Kurva Durasi Debit. Standar Nasional Indonesia Nomor 6738-2015. Jakarta (ID): Badan Standardisasi Nasional.

[DepPU] Departemen Pekerjaan Umum. 2000. Kriteria Perencanaan Air Bersih. Jakarta (ID): Direktorat Pengembangan Air Minum, Dirjen Cipta Karya.

[DepPU] Departemen Pekerjaan Umum. $2007 . \quad$ Penyelenggaraan Pengembangan Sistem Air Minum. Peraturan Menteri Pekerjaan Umum Nomor 18/PRT/M/2007. Jakarta (ID): Direktorat Pengembangan Air Minum, Dirjen Cipta Karya.

Gaib DTY, Tanudjaja L, Hendratta AL. 2016. Perencanaan Peningkatan Kapasitas Produksi Air Bersih Ibukota Kecamatan Nuangan. Jurnal Sipil Statik 4(8) : 481-490.

Hasibuan DAF. 2013. Analisis kebutuhan dan ketersediaan air baku di Kabupaten Tangerang [skripsi]. Bogor(ID): Institut Pertanian Bogor.

Kodotie RJ, Sjarief R. 2005. Pengelolaan Sumber Daya Air Terpadu. Yogyakarta (ID): Andi.

Langi OA. 2007. Analisis neraca air meteorologi untuk kekritisan DAS pada karakteristik bentuklahan karst dan vulkanik[Tesis]. Yogyakarta (ID) : Universitas Gadjah Mada.

Mega IM. 2010. Klasifikasi Tanah dan Kesesuaian Lahan. Bali (ID): Udayana Press.

[MenLH] Menteri Lingkungan Hidup. 2007. Pedoman Pengkajian Teknis untuk Menetapkan Kelas Air. Peraturan Menteri Negara Lingkungan Hidup Nomor 01 Tahun 2007. Jakarta(ID): Menteri Lingkungan Hidup.

Mokoginta FC, Manganka IR. 2015. Peningkatan Sistem Penyediaan Air
Bersih Di Kelurahan Pinaras. Jurnal Sipil Statik. 3(5): 322-330.

Pratomo DS, Astuti EZ. 2015. Analisis

Regresi Dan Korelasi Antara Pengunjung Dan Pembeli Terhadap Nominal Pembelian Di Indomaret Kedungmundu Semarang Dengan Metode Kuadrat Terkecil. Jurnal Statistika. 1(1):3.

[PRI] Pemerintah Republik Indonesia. 2001. Pengelolaan Kualitas Air dan Pengendalian Pencemaran Air. Peraturan Pemerintah No. 82 Tahun 2001. Jakarta (ID): Pemerintah Republik Indonesia.

Purnama S, Suyono, Sulaswono B. 2007. Sistem Akuifer dan Potensi Airtanah Daerah Aliran Sungai (DAS) Opak. Jurnal Geografi. 21(2): 111-122.

Sari IK, Limantara LM, Priyantoro D. 2006. Analisa Ketersediaan Dan Kebutuhan Air pada DAS Sampean. Jurnal Pengairan. 1(1):3.

Soemarto CD. 1986. Hidrologi Teeknik Edisi 1. Surabaya(ID): Usaha Nasional.

Solin W. 2012. Analisis Kebutuhan dan Ketersediaan Air Secara Meteorologis di Daerah Aliran Sungai Deli Provinsi Sumatera Utara. Jurnal Geografi. 1(1):6.

Sosrodarsono S, Takeda K. 1993. Hidrologi untuk Pengairan. Jakarta (ID): PT Pradnya Paramita.

Sudjana. 1982. Metode Statistika. Bandung (ID): Tarsito.

Suryadmaja IB, Norken IN, Dharma S. 2015. Karakteristik Pola Pemakaian dan Pelayanan Air Bersih Di Wilayah PAM PT.Tirtaartha Buanamulia. Jurnal Spektran. 3(1): 21.

Syafruddin M, Hakim L, Despa D. 2007. Metode Regresi Linier untuk Prediksi KebutuhanEnergi Listrik Jangka Panjang (Studi Kasus Provinsi Lampung). Jurnal 
Informatika dan Teknik Elektro Terapan. 1(1): 2.

Syilfi S, Ispriyanti D, Safitri D. 2012. Analisis Regresi Linear Piecewise Dua Segmen. Jurnal Statistika. 1(1):220.

Tambunan RA. 2013. Peran Pdam Dalam Pengelolaan Bahan Air Baku Air Minum Sebagai Perlindungan Kualitas Air Minum. Jurnal Ilmiah. 1(1):9.

Taufik M. 2005. Evaluasi dan Pengembangan Sistem Distribusi Air Bersih Utama Kota Niamey, Niger. Bandung (ID): ITB Press

Todd DK. 1980. Groundwater Hidrology, Second Edition. California (US): John Willey \& Sons.

Triyadi D, Wahyuni S. 2016. Perencanaan Instalasi Pengolahan Air Minum di Kec.Jatinangor dan Kec. Cimanggu Kab. Sumedang. Bandung (ID): Unpas Press.

Twort AC, Ratnayaka DD. 2003. Water Supply, Fifth Edition. London (GB) : IWA Publishing.

Widiyono MG. 2016. Analisis Neraca Air Metode Thornthwaite Mather Kaitannya Dalam Pemenuhan Kebutuhan Air Domestik Di Daerah Potensi Rawan Kekeringan Di Kecamatan Trowulan Kabupaten Mojokerto. Jurnal Pengairan. 1(1): 14-15.

Wijayanti P, Noviani R, Tjahjono GA. 2015. Dampak Perubahan Iklim Terhadap Imbangan Air Secara Meteorologis Dengan Menggunakan Metode Thornthwaite Mather Untuk Analisis Kekritisan Air Di Karst Wonogiri. Jurnal Geomedia. 13(1): 37-38.

Yuliani Y, Rahdriawan M. 2014. Kinerja Pelayanan Air Bersih Berbasis Masyarakat di Tugurejo Kota Semarang. Jurnal Pembangunan Wilayah \& Kota. 10(3):248-264.
Zulkipli, Soetopo W, Prasetijo H. 2013. Analisa Neraca Air Permukaan DAS Penggung Untuk Memenuhi Kebutuhan Air Irigasi dan Domestik Penduduk Kabupaten Lombok Tengah. Jurnal Pengairan. 1(1):89. 